\title{
COMUNIDADE FÚNGICA ASSOCIADA A BROTAÇÕES DE Eucalyptus EM JARDIM CLONAL E SEU ENVOLVIMENTO NA ETIOLOGIA DA PODRIDÃO DE ESTACAS UTILIZADAS PARA A PRODUÇÃO DE MUDAS.
}

\section{ANDRÉ LUIS PARADELA}

Engenheiro Agrônomo

Orientador: Prof. Dr. IVAN PAULO BEDENDO

Dissertação apresentada à Escola Superior de Agricultura "Luiz de Queiroz", da Universidade de São Paulo, para obtenção do Título de Mestre em Agronomia. área de concentração: Fitopatologia.

P I R A C I C A B A

Estado de São Paulo - Brasil

Junho - 1998 
Dados Internacionais de Catalogação na Publicação (CIP) DIVISÃo DE BIBLIOTECA E DOCUMENTAÇÃO - Campus "Luiz de Queiroz"/USP

Paradela, André Luis

Comunidade fúngica associada a brotaçōes de Eucalyptus em jardim clonal e seu envolvimento na etiologia da podridão de estacas utilizadas para a produção de mudas / André Luis Paradela. - - Piracicaba, 1998.

$43 \mathrm{p}$.

Dissertação (mestrado) - - Escola Superior de Agricultura Luiz de Queiroz, 1998.

Bibliografia.

1. Brotaçăo 2. Etiologia 3. Fungicida 4. Fungo endofítico 5. Muda de eucalipto 6. Patogenicidade 7. Podridão-de-estaca 8. Tratamento quimico I. Titulo 
A minha noiva

Minéia

dedico 
Aos meus pais

Osvaldo

e

Marlene

e aos meus irmãos

Afonso

e

Juliana

ofereço 


\section{AGRADECIMENTOS}

O autor agradece a todos que direta ou indiretamente contribuíram para a realização deste trabalho, em especial:

- Ao Prof. Dr. Ivan Paulo Bedendo, pela orientação e dedicação demonstradas durante o curso.

- A todos os professores, funcionários e alunos do Departamento de Fitopatologia da Escola Superior de Agricultura "Luiz de Queiroz", pelos ensinamentos e amizade demonstrados.

- Ao Conselho Nacional de Pesquisa e Desenvolvimento - CNPq, pela bolsa de estudo concedida.

- Ao Prof. Dr. Tasso Leo Krügner pela co-orientação e amizade demonstradas durante o curso.

- A VCP (Votorantin Celulose e Papel) por colaborar com a condução do ensaio.

- Aos funcionários João Luiz Florcovski e Elizandra Mangili do Departamento de Fitotecnia da Faculdade de Agronomia "Manoel Carlos Gonçalves" pelo apoio e amizade demonstrados.

- Ao diretor da Faculdade de Agronomia "Manoel Carlos Gonçalves", Eng. Agr. Celso Henrique Zuppi da Conceição, pelo apoio e confiança demonstrados durante o curso.

- À Fundação Pinhalense de Ensino pelo estímulo, apoio e compreensão demonstrados durante o curso. 


\section{SUMÁRIO}

LISTA DE TABELAS …....................................................................

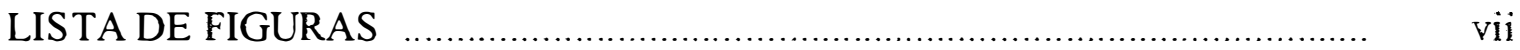

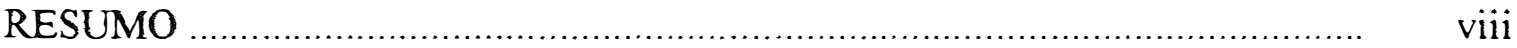

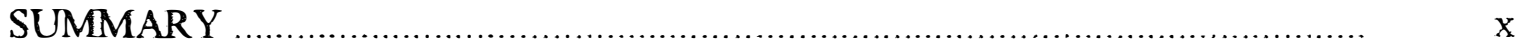

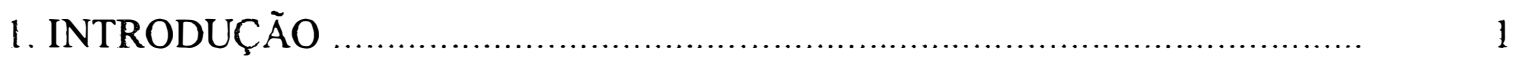

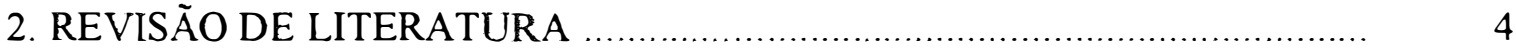

2.1. Produção comercial de mudas propagadas vegetativamente .................... 4

2.2. Etiologia da podridão de estacas ........................................................ 5

2.3. Ocorrência endofitica de fungos ......................................................... 7

2.4. Controle químico da podridão de estacas de eucalipto …........................ 10

3. MATERIAL E MÉTODOS _..................................................................... 12

3.1. Levantamento da Comunidade fúngica endofitica em jardim clonal ....... 12

3.2. Teste de patogenicidade ................................................................. 16

3.3. Tratamento de touças no jardim clonal ................................................ 18

3.4. Tratamento químico de estacas ....................................................... 18

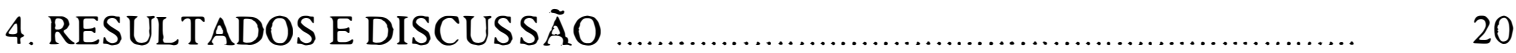

4.1. Levantamento da Comunidade fúngica endofitica em jardim clonal ........ 20

4.2. Teste de patogenicidade ................................................................. 25

4.3. Tratamento de touças no jardim clonal ............................................... 31

4.4. Tratamento químico de estacas .........................................................

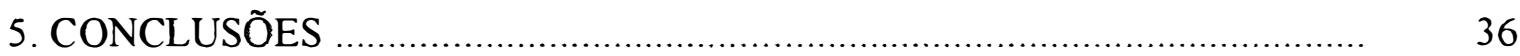

REFERÊNCIAS BILIOGRÁFICAS …….................................................. 38 


\section{LISTA DE TABELAS}

Tabela 1. Incidência (\%) de fungos endofiticos em brotos de eucalipto provenientes de touças tratadas e não tratadas com fungicidas durante o período de um ano correspondente a seis ciclos de corte comercial

Tabela 2. Patogenicidade e reisolamento dos fungos endofiticos mais freqüentemente associados às brotações assintomáticas de jardim clonal e seu efeito sobre a formação de calos de estacas de eucalipto, avaliados aos 12 dias após a estaquia

Tabela 3. Patogenicidade e reisolamento dos fungos endofiticos mais freqüentemente associados às brotações assintomáticas de jardim clonal e seu efeito sobre o enraizamento de estacas de eucalipto, avaliados aos 25 dias após a estaquia

Tabela 4. Efeito de tratamento fungicida sobre a ocorrência de podridão e formação de calos em estacas de eucalipto, avaliado 12 dias após a estaquia

Tabela 5. Efeito de tratamento fungicida sobre a ocorrência de podridão e enraizamento em estacas de eucalipto, avaliado 25 dias após a estaquia 


\section{LISTA DE FIGURAS}

Figura 1. Quantidade de chuva $(\mathrm{mm})$ durante os meses de outubro/96 a novembro/97 no jardim clonal onde as amostras foram coletadas. Santa Rita do Passa Quatro - SP

Figura 2. Média das temperaturas máximas e mínimas $\left({ }^{\circ} \mathrm{C}\right)$ anotadas durante os meses de outubro/96 a novembro/97 no local do experimento. Santa Rita do Passa Quatro - SP 
COMUNIDADE FÚNGICA ASSOCIADA A BROTAÇÕES DE Eucalyptus EM

JARDIM CLONAL E SEU ENVOLVIMENTO NA ETIOLOGIA DA PODRIDÃO DE ESTACAS UTILIZADAS PARA A PRODUÇÃO DE MUDAS.

Autor: André Luis Paradela

Orientador: Prof. Dr. Ivan Paulo Bedendo

RESUMO

A podridão de estacas se constitui num sério problema para a produção de mudas de eucalipto através de estaquia. Brotos provenientes do jardim clonal infectados por fungos endofiticos podem ser responsáveis pela introdução do inóculo primário nas casas de vegetação. A doença é comprovadamente causada por espécies do gênero Cylindrocladium e Rhizoctonia, porém outros fungos são suspeitos de estarem associados à podridão.

Com o objetivo de se conhecer a comunidade fúngica endofitica possivelmente associada à podridão e de se estudar a etiologia da doença, foi feito um levantamento em um jardim clonal de um híbrido de Eucalyptus grandis $\mathrm{x}$ Eucalyptus urophylla, localizado em Santa Rita do Passa Quatro, SP, através de isolamentos em meio de cultura, durante o período de outubro de 1996 a novembro de 1997. Foram realizados testes de patogenicidade em casa de vegetação com os fungos que predominaram neste levantamento. 
Visando avaliar o controle químico da doença, foram efetuadas aplicações foliares semanais de benomyl $(0,5 \mathrm{~kg} / \mathrm{ha})$ e oxicloreto de cobre $(1,1 \mathrm{~kg} / \mathrm{ha})$ iniciadas, duas semanas após o corte comercial, durante a etapa de levantamento. Posteriormente, foi também testada a imersão de estacas comerciais em suspensões de captan (1,5 g i.a./l) e de benomyl $(0,75 \mathrm{~g}$ i.a. $/ 1)$.

Diversos gêneros foram detectados como ocorrendo endofiticamente nos brotos, aparecendo com maior freqüência Botryosphaeria, Colletotrichum e Guignardia. Foi demonstrado que Colletotrichum e Botryosphaeria estão envolvidos na etiologia da doença e que Cylindrocladium candelabrum é o principal patógeno responsável pela redução do enraizamento das estacas.

Quanto ao tratamento químico, a pulverização das touças no jardim clonal não se mostrou eficiente, o mesmo ocorrendo com o tratamento de imersão das estacas. 


\section{FUNGAL COMMUNITY OF EUCAL YPTUS SPROUTS IN A CLONAL GARDEN AND ITS ROLE ON THE ETIOLOGY OF CUTTING ROT.}

Author: André Luis Paradela

Adviser: Prof. Dr. Ivan Paulo Bedendo

SUMMARY

Cutting rot is a serious problem in the vegetative propagation of Eucalyptus. Cylindrocladium and Rhizoctonia are known to be the major genera of pathogens involved in the etiology of the problem. Other fungi, however, are also commonly associated endophytically with symptomless sprouts originated from the clonal garden which could also contribute to the causality of the disease after their introduction in the greenhouse with the cuttings.

A survey was carried out in order to evaluate the fungal community possibly associated with the cutting rot in the greenhouse in a commercial clonal garden located in Santa Rita do Passa Quatro, SP, during the period of october 1996 to november 1997. Two sprout samplings were made for each of the 6 commercial harvest cuts that were performed during the survey period and fungal community evaluated by plating sprout stem pieces on potato-dextrose-agar. Fungi which predominated in the survey had their pathogenicity tested trough cutting inoculation in a commercial greenhouse. 
During the survey of the fungi, foliar applications of benomyl $(0.5 \mathrm{~kg} / \mathrm{ha})$ alternated with copper oxichloride $(1.1 \mathrm{~kg} / \mathrm{ha})$ were done weekly in part of the clonal garden, in order to test an alternative for the control of the disease. In addition, a trial was carried out to test the fungicidal treatment of the cuttings before planting, by immersion in a suspension of captan $(1.5 \mathrm{~g} / \mathrm{l})$ or benomyl $(0.75 \mathrm{~g} / \mathrm{l})$.

Several genera of fungi were detected in association with the sprouts, Colletotrichum, Guignardia and Botryosphaeria being the most common ones among those that were identified. It was also demonstrated that Colletotrichum and Botryosphaeria may be involved in the etiology of the cutting rot, but were less aggressive than Cylindrocladium candelabrum, a common species found in the study area, which reduced the rooting of the cuttings.

The fungicidal sprays in disease incidence and severity as well the fungicidal cutting treatment gave no differences in relation to the non treated controls. 


\section{INTRODUÇÃO}

O gênero Eucalyptus conta com aproximadamente 600 espécies e variedades disseminadas pelos continentes, havendo espécies adaptadas para as diferentes regiões do globo (Andrade, 1961). O eucalipto foi introduzido no Brasil no ano de 1904, sendo que aproximadamente I milhão de hectares estão plantados com a cultura (ONU, 1989). A planta é utilizada para diversas finalidades, entre elas o formecimento de lenha, como madeira para construção, produção de carvão vegetal, extração de fibras para a indústria de papel e celulose, produtora de néctar para a apicultura, além da produção de óleos e taninos. Segundo a Organização das Nações Unidas (1989), o eucalipto é a espécie florestal mais amplamente disseminada, sendo cultivada em mais de cem países do mundo.

A planta de eucalipto pode ser propagada através de sementes (propagação sexuada) e através de estacas (propagação vegetativa), sendo que a opção por um desses métodos pode ser feita através da análise de vantagens e desvantagens proporcionadas por esses dois tipos de propagação. As vantagens proporcionadas pela propagação 
vegetativa (estaquia) são principalmente a maior uniformidade genética das plantas e um menor período para a produção de mudas ( 80 dias), enquanto as desvantagens envolvem um maior custo de produção destas mudas ( $\mathrm{R} \$ 120,00 /$ milheiro). As vantagens da propagação sexuada envolvem menor custo de produção ( $\mathrm{R} \$ 46,00 /$ milheiro) e maior rendimento quanto ao número final de mudas obtidas; no entanto, apresentam as desvantagens da desuniformidade genética das mudas e a exigência de um maior período de tempo para a formação das mesmas (110 dias). Apesar do custo maior, as empresas florestais apresentam a tendência de aumentar o número de mudas propagadas vegetativamente e de diminuir a propagação de mudas por sementes.

A produção de mudas por estaquia se inicia a partir da coleta de brotos obtidos de touças que constituem o jardim clonal. A partir desses brotos são obtidas as estacas de aproximadamente $80 \mathrm{~mm}$ que são plantadas em tubetes plásticos contendo o substrato específico utilizado para o enraizamento. Os tubetes plantados são colocados em bandejas de aproximadamente 200 células e são levados para viveiros localizados em casa de vegetação onde permanecem por um período de 25 dias para o desenvolvimento de novas brotações e início do enraizamento.

Um dos grandes problemas da propagação vegetativa é a diminuição na porcentagem de enraizamento das estacas, freqüentemente associada à ocorrência de podridão. A perda causada pela doença nos viveiros comerciais pode chegar a $40 \%$, conforme constatado durante visitas em algu mas empresas florestais.

Em relação à etiologia da podridão de estacas, tanto patógenos primários (Cylindrocadium spp. e Rhizoctonia solani Kuhn) como patógenos secundários (Colletotrichum spp.; Botryosphaeria ribis Grossb \& Duggar (sin. B. dothidea Moug : 
Fr. Ces. \& De Not) e Alternaria spp.) podem estar envolvidos no processo (Alfenas et al., 1989; Ferreira, 1989; Vitti et al., 1989).

Existem evidências de que os fungos envolvidos na podridão de estacas ocorrem endofiticamente em brotações sem sintomas presentes em jardins clonais (Fischer \& Petrini, 1987; Souza \& Krügner, 1995; Smith \& Wingfield, 1996). Além da possibilidade da ocorrência de fungos patogênicos endofiticamente, existe uma variação sazonal na ocorrência desses fungos em brotações, sendo que a freqüência está relacionada com as variações de temperatura e umidade durante as diferentes épocas do ano (Souza \& Krügner, 1995).

Embora não existam fungicidas registrados para o controle desses fungos patogênicos, é provável que alguns produtos fungicidas aplicados no jardim clonal possam exercer algum controle, proporcionando a coleta de brotos sadios e o conseqüente aumento da porcentagem de enraizamento de estacas.

Em razão das vantagens na obtenção de mudas através de processo vegetativo, da importância de podridão de estacas neste sistema de produção de mudas e do possível papel dos fungos endofiticos sobre a podridão de estacas, o presente trabalho teve por objetivos: detectar através de um levantamento a ocorrência de fungos endofiticos presente em brotações assintomáticas provenientes de jardim clonal e que possam estar associados à podridão de estacas; demonstrar a patogenicidade dos fungos mais freqüentemente associados à podridão; avaliar a aplicação de fungicidas no jardim clonal, visando o controle da podridão de estacas verificada nos viveiros comerciais; avaliar o tratamento químico de estacas previamente ao plantio, visando o controle dos agentes de podridão. 


\section{REVISÃO DE LITERATURA}

\subsection{Produção comercial de mudas propagadas vegetativamente}

A produção de mudas por estaquia se inicia a partir da coleta de brotos obtidos de touças que constituem o jardim clonal. O jardim clonal se constitui em uma matriz de plantas da qual brotos são retirados periodicamente, após a brotação das plantas existentes. A partir desses brotos são obtidas as estacas de aproximadamente $80 \mathrm{~mm}$ que são tratadas com hormônio para enraizamento e plantadas em tubetes plásticos contendo o substrato específico utilizado para o enraizamento. Os tubetes plantados são colocados em bandejas de aproximadamente 200 células e são levados para viveiros localizados em casa de vegetação, onde permanecem por um período de 25 dias para o desenvolvimento das brotações iniciais. Após essa etapa, as bandejas são levadas para viveiros a céu aberto, onde permanecem por um período de tempo variável até a formação final da muda. 


\subsection{Etiologia da podridão de estacas}

A podridão tem sido relatada como a grande responsável pela redução na obtenção final de mudas de eucalipto, por prejudicar o enraizamento das estacas (Demuner et al., 1988; Carvalho et al., 1989; Vitti et al., 1989). O inóculo inicial responsável pela introdução da doença nos viveiros de produção de mudas pode ser proveniente do substrato de plantio, dos tubetes usados para conter o substrato, do material cortante utilizado durante os tratos culturais ou durante a coleta de brotos no jardim clonal, da casa de vegetação que abriga o viveiro ou dos brotos assintomáticos provenientes de jardim clonal, nos quais $\mathrm{o}(\mathrm{s})$ patógeno(s) pode $(\mathrm{m})$ ocorrer endofiticamente. Segundo os referidos autores, a etiologia desta podridão envolve patógenos primários como Cylindrocladium sp. e Rhizoctonia solani, e secundários como, Colletotrichum sp., Botryosphaeria ribis e Alternaria sp. Esses patógenos têm sido freqüentemente isolados de estacas que apresentam problemas de podridão.

Um estudo da etiologia da podridão de estacas conduzido por Vitti et al. (1989) evidenciou que fungos dos gêneros Rhizoctonia (28\%) e Cylindrocladium (20\%) foram aqueles mais freqüentemente associados à podridão basal, quando estacas foram obtidas quinzenalmente de plantas de E. grandis, E. saligna e alguns híbridos de eucalipto. Foi detectado também a presença dos gêneros Colletotrichum (15\%) e Dothiorella (11\%), o que não descarta a possibilidade de serem prováveis patógenos associados à podridão.

Resultados semelhantes foram obtidos por Carvalho et al. (1989), os quais verificaram também uma maior freqüência de Cylindrocladium scoparium, 
Cylindrocadium clavatum e Rhizoctonia sp em estacas de eucalipto na fase de enraizamento. Fungos como Botryosphaeria sp. e Coniella fragariae também foram identificados após o isolamento e considerados como secundários ou como saprófitas, devido ao resultado negativo no teste de patogenicidade.

Punithalingam \& Holliday (1973), ao descreverem o gênero Botryosphaeria, relataram algumas de suas características, tais como distribuição em regiões tropicais e temperadas, causadores de sintomas tipo "die back" em culturas como abacate, olmo e Pinus, forma de penetração indireta através de ferimentos ou aberturas naturais. Mais especificamente em relação a plantas do gênero Pinus, foi observado que esse patógeno ataca mais freqüentemente quando a planta se encontra sob condições adversas de crescimento, demonstrando pouca habilidade para ser considerado patógeno principal nessa cultura.

Botryosphaeria ribis foi isolado de sintomas do tipo cancros presentes em árvores de Eucalyptus saligna. Através do teste de patogenicidade, foi demonstrado que este fungo pode realmente ser o agente causal desta doença (Fraser \& Davidson, 1985).

Smith et al. (1994), ao estudarem o cancro do eucalipto na África do Sul, concluíram que o aparecimento da doença era bastante influenciado pelas condições ambientais. Além disso, o fungo Botryosphaeria dothidea Moug \& Fr. Ces. \& De Not (sin. B. ribis Grossb \& Duggar) conhecido como causador do cancro em muitas espécies de eucalipto, foi consistentemente isolado a partir de tecidos com sintomas, sendo a sua patogenicidade confirmada através de inoculações do fungo em Eucalyptus nitens.

Smith (1934), ao pesquisar sobre hospedeiros de Dothiorella sp (estágio imperfeito de B. ribis) realizando experimentos de inoculação cruzada com isolados de 
Dothiorella sp obtidos de várias culturas, concluiu que todas as espécies do fungo são idênticas. Estas espécies estão distribuídas em países de clima tropical e temperado, atacando 34 gêneros de 20 famílias de plantas, incluindo rosáceas, palmáceas, mirtáceas e outras famílias de importância econômica. Esse autor concluiu também que quando se promove ferimentos nas plantas e se emprega quantidades adequadas de inóculo, determinadas espécies hospedeiras se mostram altamente suscetiveis, enquanto outras, se apresentam como resistentes.

\subsection{Ocorrência endofitica de fungos}

Fisher et al. (1993) constataram a presença de B. dothidea ocorrendo endofiticamente em plantas de eucalipto, após sucessivos isolamentos. Evidência da ocorrência endofitica de patógenos foi obtida em outros trabalhos destes mesmos autores (Fisher \& Petrini, 1987), os quais isolaram 12 espécies de fungos endofiticos provenientes de folhas e caules de Suaeda fruticosa, onde Colletotrichum phyllachoroides foi consistentemente isolado de folhas.

Carroll (1990), em trabalho de pesquisa com fungos endofiticos como patógeno de plantas, enfatizou particularmente a ocorrência dos gêneros Fusarium, Phyllosticta e fungos da família Xylariaceae. Fisher et al. (1992) relataram que aproximadamente 30 isolados de diversos fungos endofiticos foram obtidos de 5 espécies de Thymus; a 
espécie Colletotrichum gloeosporioides foi encontrada em somente uma espécie ( $T$. serpyllum), enquanto que Alternaria alternata, Alternaria sp., Colletotrichum dematium e Pleorospora herbarum foram predominantes em caules de outras 4 espécies desta planta.

Dothiorella dominicana, Dothiorella mangiferae, Lasiodiplodia (Botryoplodia) theobromae, Phomopsis mangiferae, Cytosphaera mangiferae, Pestalotiopsis sp., Dothiorella sp. e Alternaria alternata, entre outros, foram encontrados ocorrendo endofiticamente nos tecidos de caule de mangueira, antes da emergência da inflorescência. Colonização endofitica por Dothiorella spp. e P. mangiferae foi detectada em tecidos do caule, inflorescência e do pedicelo do fruto maduro provenientes de árvores não tratadas e árvores tratadas regularmente com fungicidas cúpricos. A colonização por fungos endofiticos de tecidos da inflorescência e do pedicelo pode ser uma via primária para a infecção do fruto por outros patógenos principalmente Glomerella cingulata, agente causal de antracnose (Johnson et al., 1992).

A ocorrência endofitica de $B$. dothidea em tecidos sadios de pêssego, foi relatada por Pusey \& Bertrand (1993), os quais concluíram que a severidade da doença foi positivamente correlacionada com a disponibilidade de água para germinação dos esporos e que tecidos de planta, mesmo sem ferimentos, são suscetiveis à invasão pelo patógeno durante quase toda a estação de crescimento.

Gindrat \& Pezet (1994) utilizaram Paraquat como ferramenta para deteç̧ão rápida de infecção latente de fungos não endofiticos e fungos endofiticos na cultura da videira. Os resutados revelaram que este produto químico induziu o desenvolvimento de infecção latente do fungo Botrytis cinerea. 
Após levantamento realizado em jardim clonal de eucalipto, Souza \& Krügner (1995) constataram a ocorrência de B. ribis e Colletotrichum sp. que, segundo os autores, podem se destacar como potenciais causadores da doença na cultura. Verificaram também que existe uma sazonalidade de ocorrência desses microrganismos potencialmente patogênicos, pois em periodo de estiagem prolongada não verificaram a ocorrência desses fungos, mediante isolamentos feitos a partir de brotações sem sintomas.

Fungos endofiticos foram isolados de 45 espécies e variedades de plantas do gênero Pimus plantados na cidade de Kyoto, no Japão. Phialocephala sp. foi a espécie mais freqüentemente obtida em isolamentos feitos a partir da porção basal do caule de plantas (Hata \& Futai, 1996).

Smith et al. (1996) também encontraram o fungo Phialocephala sp. em várias espécies de eucalipto com freqüências de $93 \%$ em E. smithii, $77 \%$ em E. camaldulensis, $63 \%$ em E. grandis e $57 \%$ em E. nitens. Este fungo, causador de cancro e doenças do tipo “die back', ocorria endofiticamente nas amostras provenientes de plantas que sofreram um estresse e passaram a manifestar sintomas. 


\subsection{Controle químico da podridão de estacas de eucalipto}

Alfenas et al. (1988) constataram que um dos isolados de C. scoparium foi resistente ao fungicida benomyl mesmo quando se utilizou concentrações de $960 \mathrm{ppm}$ de ingrediente ativo; no entanto, outros isolados patogênicos deste fungo foram inibidos com 30 ppm do produto. Ensaios conduzidos por Bedendo \& Krügner (1987) mostraram que 10 e $100 \mathrm{ppm}$ de benomyl promoveram, respectivamente, a inibição total de crescimento micelial e da germinação de esporos de Cylindrocladium pteridis. Estes mesmos autores relataram que chlorothalonil na concentração de 100 ppm reduziu em $60 \%$ o crescimento micelial deste fungo. Alfenas et al. (1988) encontraram tolerância de C. scoparium a benomyl na concentração de 1000 ppm e sensibilidade a thiram na concentração de 2000 ppm, sugerindo que fungicidas com modo de ação diferente devem ser usados alternadamente para evitar o aparecimento de raças tolerantes.

Estudando o efeito de alguns fungicidas na erradicação "in vitro" de conídios e micélio de C. scoparium, Demuner et al. (1988 a) mostraram que a erradicação total de esporos foi obtida com os fungicidas captan a $1600 \mathrm{ppm} / 10$ minutos, thiram a 2500 ppm/10 minutos, captan a $2400 \mathrm{ppm}+$ benomyl a $480 \mathrm{ppm} / 2$ minutos, thiram a 3300 $\mathrm{ppm}+$ benomyl a $480 \mathrm{ppm} / 2$ minutos e hipoclorito de sódio $(\mathrm{NaOCl})$ a $130 \mathrm{ppm}$ de cloro ativo por 0,5 minuto. Em outro trabalho, estes mesmos autores (Demuner et al., 1988 b) não conseguiram erradicar "in vitro" conídios e micélio de $C$. scoparium, quando benomyl foi usado na concentração de $0,5 \mathrm{~g}$ i.a./l por um tempo de exposição de 20 minutos; no entando, o micélio do fungo foi erradicado em tratamentos com $0,12 \mathrm{~g}$ 
do produto/l de água durante 2 minutos. Fegatex na dose de 2 1/300 1 de água foi o produto mais eficiente testado por Takahashi et al. (1998) no controle de Cylindrocladium spp., Fusarium spp., Pythium spp., Phytophthora spp., Botrytis cinerea, em ensaios realizados "in vitro".

Ferreira et al. (1992) analisaram o tratamento rotineiro de estacas de eucalipto para enraizamento feito pela imersão das estacas em suspensão aquosa de benomyl a 500 ppm e constataram que este fungicida nesta concentração não foi assimilado pelas estacas, nem via casca e nem via corte basal, após imersão por até 20 minutos. Constataram também que benomyl a 480 ppm não foi eficiente para erradicar conídios de C. scoparium, mesmo após 30 minutos de tratamento das estacas com este produto.

Takahashi et al. (1998), na tentativa de controlar as principais doenças que ocorrem em estacas de eucalipto, testaram alguns fungicidas visando o controle de Cylindrocladium spp., Fusarium spp., B. ribis, Colletotrichum spp. e B. cinerea. Os tratamentos captan + Benlate pulverizados em jardim clonal, captan + Benlate pulverizados no jardim clonal associado com captan + Benlate em tratamento de estacas, captan + Benlate pulverizados no jardim clonal associado com Fegatex em tratamento de estacas, Fegatex pulverizado em jardim clonal associado com captan + Benlate em tratamento das estacas e Fegatex pulverizado em jardim clonal associado com Fegatex em tratamento das estacas destacaram-se como os melhores tratamentos.

Em relação à persistência de fungicidas em plantas, Bedendo \& Krügner (1988) demonstraram que a incorporação de benomyl ao solo pode proteger mudas de eucalipto em relação ao ataque de $C y$ lindrocladium sp. por até 53 dias após a emergência das plantas. 


\section{MATERIAL E MÉTODOS}

\subsection{Levantamento da comunidade fúngica endofitica em jardim clonal}

A coleta de brotos de eucalipto sem sintomas foi efetuada em touças do jardim clonal localizado na Fazenda Cara Preta pertencente ao grupo Votorantin Celulose e Papel - VCP/CELPAV, situada no município de Santa Rita do Passa Quatro, Estado de São Paulo. Os dados pluviométricos e de temperatura registrados para o local durante o período de realização dos ensaios estão apresentados nas Figuras 1 e 2.

Foi escolhido o clone G-31, híbrido de E. grandis $x$ E. urophylla plantado no dia 02/05/1995, no espaçamento de $0,5 \times 0,5 \mathrm{~m}$ ocupando uma área total de $3.570 \mathrm{~m}^{2}$. No plantio, foi utilizado para esta área, $130 \mathrm{~kg}$ da fórmula 06-28-06 e a adubação de manutenção foi feita com a fórmula 10-05-10, em aplicação foliar. As plantas também receberam tratos culturais do tipo limpeza de touças, adubação orgânica com esterco de frango e irrigação. 
As amostras foram colhidas durante o período compreendido entre outubro/96 e novembro/97. Doze coletas foram feitas durante o periodo de ensaio, representando seis ciclos de corte: out-nov/96, dez 96/jan 97, fev-mar/97, maio-junho/97, agostooutubro/97 e nov/97. Para cada ciclo foram coletadas duas amostras, uma aos 40 e outra aos aproximadamente 60 dias após o último corte comercial. Ressalta-se que para o $5^{\circ}$ ciclo de corte, uma das amostras foi coletada aos 40 dias e a outra aos 100 dias, acompanhando o cronograma de corte da empresa.

As amostras constaram de brotos provenientes de oito touças, sendo quatro touças tratadas com fungicida e quatro não tratadas. Em cada coleta, foram amostrados quatro brotos, de aproximadamente $20 \mathrm{~cm}$ de comprimento, por touça, totalizando 32 brotos. Assim, obteve-se metade dos brotos provenientes de touças tratadas e outra metade de touças não tratadas.

Os brotos amostrados foram lavados em água corrente e em seguida subamostras de $5 \mathrm{~mm}$ de comprimento foram obtidas de cada broto, em número de três, correspondentes às partes basal, mediana e apical dos brotos.

As sub-amostras foram desinfestadas superficialmente com álcool $70 \%$ e posteriormente imersas em uma solução de hipoclorito de sódio ( $1 \%$ de cloro ativo) por um periodo de 30 segundos. O plaqueamento foi feito em BDA (batata-dextrose-àgar) e o material foi incubado a $22{ }^{\circ} \mathrm{C}$, sob condicões de $12 \mathrm{~h}$ de luz/12 h de escuro, durante 07 dias. A identificação dos fungos foi feita usando microscópio óptico e, particularmente, para a determinação da espécie de $C y$ lindrocladium foi utilizado microscópio eletrônico de varredura. 


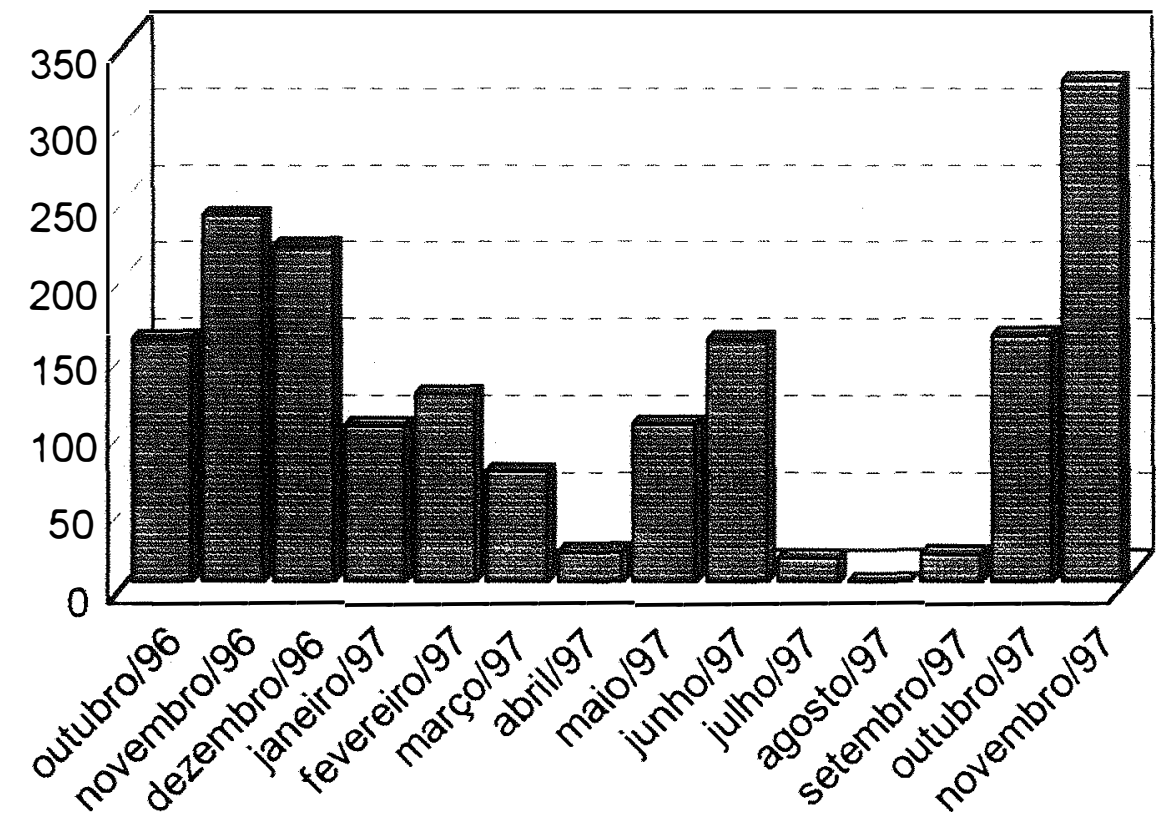

Figura 1. Quantidade de chuva $(\mathrm{mm})$ durante os meses de outubro/96 a novembro/97 no jardim clonal onde as amostras foram coletadas. Santa Rita do Passa Quatro SP. 


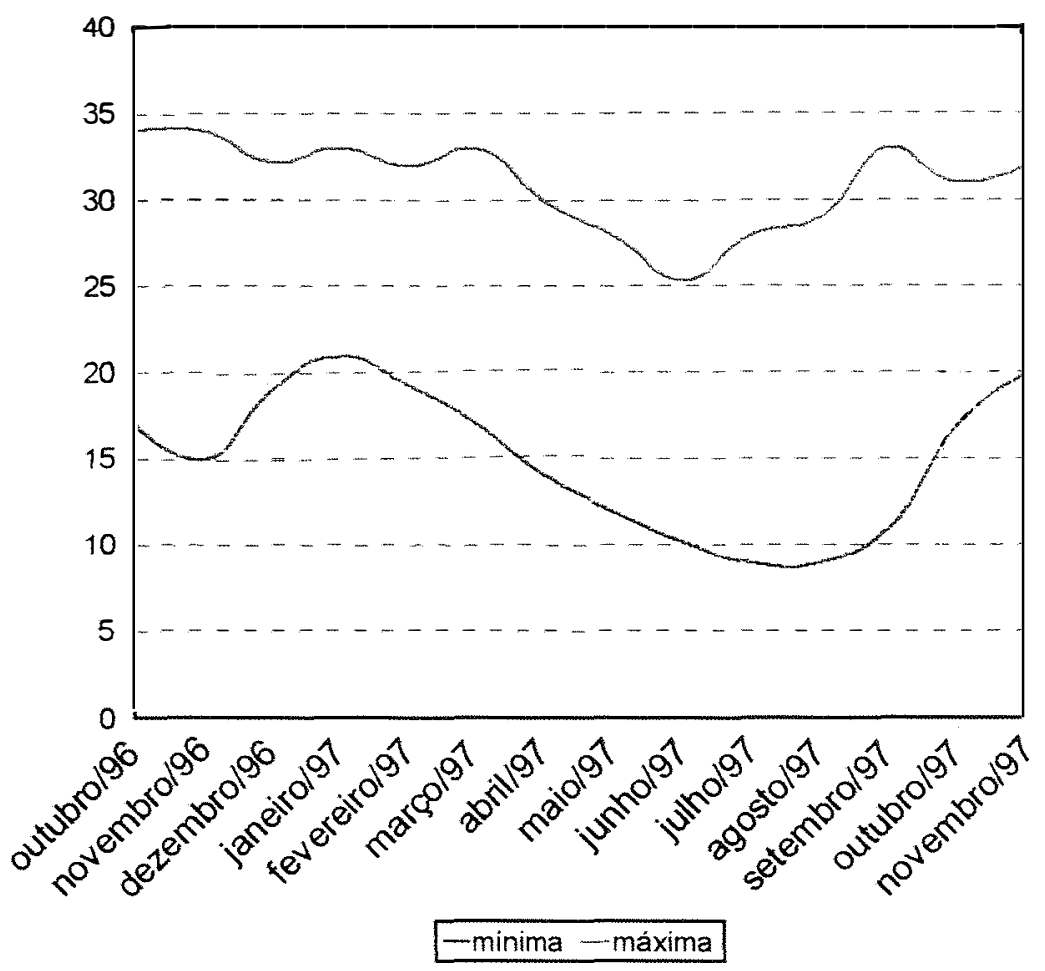

Figura 2. Média das temperaturas máximas e mínimas $\left({ }^{\circ} \mathrm{C}\right)$ anotadas durante os meses de outubro/96 a novembro/97 no local do experimento. Santa Rita do Passa Quatro-SP. 


\subsection{Teste de patogenicidade}

Os fungos mais freqüentemente isolados a partir dos brotos, provenientes de plantas do jardim clonal, foram mantidos em tubos de ensaio contendo BDA. A partir dos tubos, cada isolado foi repicado para placas contendo BDA e mantido à temperatura ambiente em torno de $22^{\circ} \mathrm{C}$, sob condições de $12 \mathrm{~h}$ de luz/12 h de escuro. Discos de micélio de aproximadamente $0,5 \mathrm{~cm}$ de diâmetro foram retirados dos bordos de colônias com 7 dias de idade e transferidos para frascos de Erlenmeyer contendo $100 \mathrm{~g}$ de sementes de trigo, previamente umedecidas em $70 \mathrm{ml}$ de água e autoclavadas. Uma semana após esta transferência, as sementes de trigo colonizadas foram incorporadas ao substrato normalmente utilizado pela VCP para a produção de mudas, na proporção de 1 parte de inóculo para 5 partes de substrato. O substrato foi constituído por uma mistura de $60 \%$ de palha de arroz carbonizada, $30 \%$ de vermiculita e $10 \%$ de substrato denominado Estaca 1, produzido comercialmente pela Eucatex. O substrato infestado pelos diversos isolados foi acondicionado em tubetes plásticos utilizados rotineiramente para o desenvolvimento de mudas a partir do enraizamento das estacas. Cerca de $80 \%$ do volume do tubete foi primeiramente preenchido com o substrato normal utilizado pela empresa, e os $20 \%$ restante (aproximadamente $2 \mathrm{~cm}$ ), foram preenchidos com o substrato infestado pelos isolados. Estacas de aproximadamente $8 \mathrm{~cm}$ de comprimento obtidas dos brotos originalmente retirados das touças foram tratadas com hormônio AIB (ácido indol butílico) e individualmente plantadas nos tubetes contendo substrato inoculado com as sementes de trigo colonizadas pelos diferentes isolados. $\mathrm{O}$ tratamento 
testemunha foi representado por substrato contendo sementes de trigo autoclavadas, porém não colonizadas pelos fungos.

O delineamento estatístico utilizado fó o de blocos ao acaso com seis tratamentos e quatro repetições, totalizando vinte e quatro parcelas sendo que cada parcela foi representada por 32 tubetes. Cada tratamento foi representado pela infestação do solo por um isolado pertencente a um dos cinco diferentes gêneros de fungos mais frequentemente isolados dos brotos provenientes de touças do jardim clonal. $\mathrm{O}$ outro tratamento foi representado pela testemunha, cujo substrato não foi infestado.

Após o plantio ou estaquia, os tubetes foram levados para a casa de vegetação da VCP, onde se encontravam os viveiros de produção de mudas. A primeira avaliação foi feita aos doze dias e a segunda aos vinte e cinco dias após o plantio. Como critério, foi considerada como doente a estaca que exibia área de coloração escura (lesão), supostamente causada pelo patógeno. A incidência foi representada pelo número de estacas exibindo área basal escura e a severidade foi avaliada através da medida ( $\mathrm{mm}$ ) da extensão desta área escurecida ou lesionada. Foi avaliado também o efeito dos fungos sobre a formação de calos e sobre o enraizamento das estacas, através da contagem de estacas apresentando calos ou primórdios de raiz.

Após a avaliação, procedeu-se ao reisolamento na tentativa de se recuperar os fungos associados à podridão da estaca. A metodologia utilizada para o reisolamento foi idêntica àquela descrita no item 3.1., referente ao isolamento. 


\subsection{Tratamento de touças no jardim clonal}

As touças tratadas ocupavam uma área de aproximadamente $1.800 \mathrm{~m}^{2} \mathrm{e}$ receberam tratamento fungicida na forma de pulverizações semanais. Foi utilizado para aplicação um pulverizador costal com capacidade para 20 1, bico cônico 110/04, sendo as pulverizações feitas a partir da $2^{\mathrm{a}}$ semana após o corte comercial. Estas pulverizações visavam proteger as novas brotações contra o ataque de patógenos. As aplicações foram feitas alternadamente com benomyl na dose de $0,5 \mathrm{~kg} / \mathrm{ha}$ e oxicloreto de cobre na dose de $1,1 \mathrm{~kg} / \mathrm{ha}$ com volume de calda de aproximadamente 300-400 $\mathrm{l} / \mathrm{ha}$, até uma semana antes da última coleta de amostras.

\subsection{Tratamento químico de estacas}

Para o tratamento químico das estacas, foram utilizados os fungicidas benomyl e captan na concentração de $0,75 \mathrm{~g} / \mathrm{l}$ e $1,5 \mathrm{~g} / \mathrm{l}$, respectivamente. A escolha desses fungicidas

foi feita em função do uso corrente desses produtos pelas empresas que utilizam a produção de mudas por propagação vegetativa. Estacas não tratadas serviram como testemunha.

Estacas de aproximadamente $70 \mathrm{~mm}$ foram obtidas de brotos oriundos de touças 
do jardim clonal e imersas em suspensões fungicidas por um período de tempo de 5 minutos. Após o tratamento fungicida, a base das estacas foi imersa em hormônio AIB (ácido indol butílico) e plantadas em tubetes contendo o substrato comercial para produção de mudas descrito no ítem 3.2. O material foi levado para a casa de vegetação, onde permaneceu por um período de 25 dias, tempo necessário para o enraizamento das estacas.

O delineamento estatístico utilizado foi o de blocos ao acaso com 3 tratamentos e 3 repetições, totalizando 9 parcelas com 70 tubetes por parcela. Os tratamentos foram representados por benomyl, captan e testemunha sem fungicida.

A primeira avaliação foi realizada aos doze dias e a segunda aos vinte e cinco dias após o plantio ou estaquia. Os critérios adotados foram idênticos aqueles descritos no item 3.2. Após a avaliação, procedeu-se ao isolamento do patógeno a partir das áreas escurecidas (lesões) presentes nas estacas. O isolamento foi conduzido de modo idêntico ao isolamento de fungos descrito no item 3.1. 


\section{RESULTADOS E DISCUSSÃO}

\subsection{Levantamento da comunidade fúngica endofítica em jardim clonal}

Com base no levantamento realizado no jardim clonal durante o período de um ano, os isolamentos realizados a partir das amostras coletadas de touças tratadas e não tratadas permitiram obter uma grande diversidade de fungos associados aos brotos assintomáticos de eucalipto (Tabela 1). Foram obtidos, em cultura pura; 20 isolados, inicialmente diferenciados entre si por algumas características apresentadas pelas colônias, principalmente coloração e tipo de micélio. Exames mais detalhados, realizados com o auxilio de microscopia, permitiram a identificação de 11 gêneros. A dificuldade para identificação dos demais isolados foi devida à ausência de esporos ou de qualquer outra estrutura típica de reprodução. Praticamente, a totalidade dos isolados não identificados ocorreu com baixa freqüência durante o levantamento realizado no período de um ano. Mesmo alguns dos 11 gêneros identificados apareceram nos isolamentos numa freqüência muito baixa. 


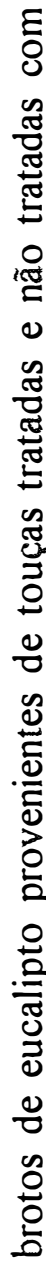

\begin{tabular}{|c|c|c|c|c|c|c|c|c|c|c|c|c|c|c|}
\hline \multirow[t]{2}{*}{ న్ } & \multirow{2}{*}{ 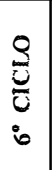 } & \multirow{2}{*}{$\begin{array}{l}\frac{n}{5} \\
\frac{\sigma}{\sigma}\end{array}$} & 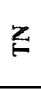 & 1 & 1 & 1 & $\begin{array}{l}0 \\
\text { in } \\
m\end{array}$ & 1 & 1 & 1 & 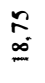 & 1 & 1 & 1 \\
\hline & & & $t$ & 1 & 1 & 1 & : & $i$ & 1 & 1 & $\dot{i}$ & 1 & 1 & 1 \\
\hline & \multirow{4}{*}{$\begin{array}{l}\frac{g}{U} \\
\text { in } \\
\text { in }\end{array}$} & \multirow{2}{*}{$\begin{array}{l}n \\
\text { à } \\
\vdots \\
\vdots\end{array}$} & 品 & 1 & 1 & ! & 1 & 1 & $!$ & 1 & 1 & 1 & 1 & $!$ \\
\hline & & & $E$ & ชี & 1 & శ్ & 1 & 1 & 1 & 1 & 1 & 1 & 1 & 1 \\
\hline & & \multirow{2}{*}{$\begin{array}{l}q \\
\frac{y}{a} \\
o\end{array}$} & $z$ & $\begin{array}{l}\tilde{z} \\
\text { - }\end{array}$ & 1 & చै & $\stackrel{\tilde{I}}{\simeq}$ & 1 & 1 & 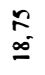 & حै & 1 & 1 & 1 \\
\hline & & & $E$ & $\underset{\sim}{2}$ & 1 & \begin{tabular}{l}
0 \\
\multirow{z}{*}{}
\end{tabular} & 0 & 1 & 1 & $\underset{0}{0}$ & 1 & & 1 & \\
\hline
\end{tabular}

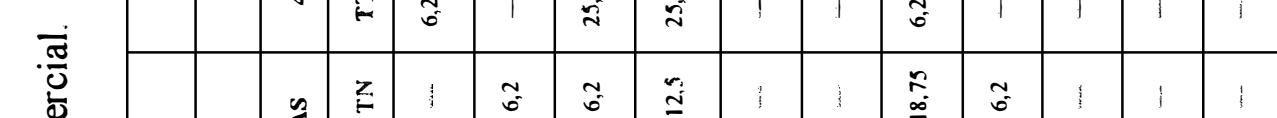

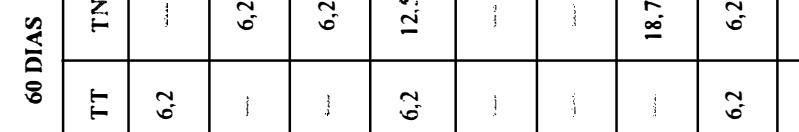

氜 孞它

\begin{tabular}{l|l|l|l|l|}
\hline$\underline{x}$ & $\geq$ & $i$ & 1 & 1
\end{tabular}

0

$\frac{0}{0}$

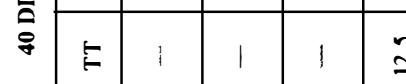

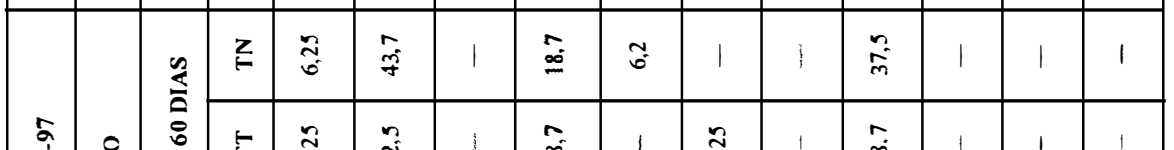

을

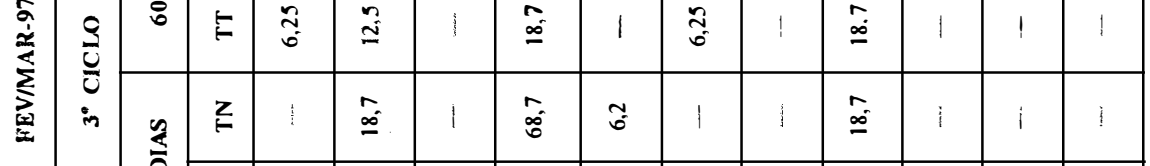

造

을

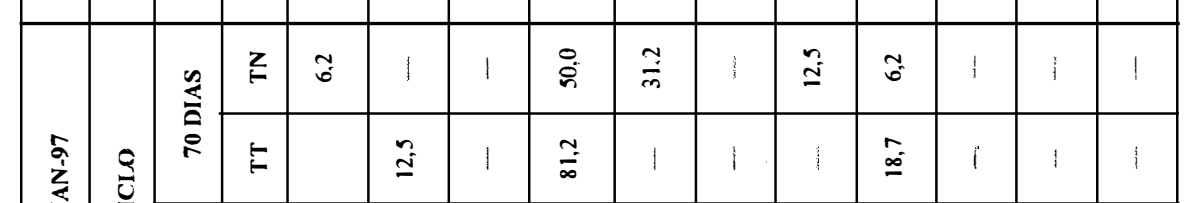



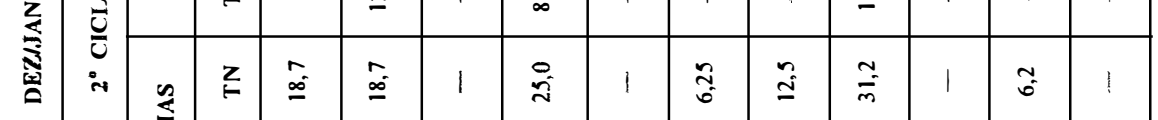

员

음

융

\begin{tabular}{|c|c|c|c|c|c|c|c|c|c|c|c|}
\hline 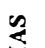 & $k$ & $\stackrel{\infty}{\infty}$ & $\stackrel{\infty}{0}^{-1}$ & 1 & $\tilde{\lambda}$ & 1 & శี & $\simeq$ & $\bar{m}$ & 1 & $0^{\circ}$ \\
\hline & $E$ & $\stackrel{-1}{m}$ & $\stackrel{n}{\simeq}$ & 1 & ? & 1 & 1 & $\stackrel{n}{\simeq}$ & $\stackrel{0}{\infty}^{r}$ & 1 & 1 \\
\hline
\end{tabular}

$\frac{0}{0}$

2

\begin{tabular}{|c|c|c|c|c|c|c|c|c|c|c|c|c|c|c|}
\hline \multirow{4}{*}{ 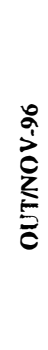 } & \multirow{4}{*}{$\begin{array}{l}\frac{9}{0} \\
\text { d } \\
:\end{array}$} & \multirow{2}{*}{$\begin{array}{l}\text { ñ } \\
8 \\
8\end{array}$} & $\underline{Z}$ & 1 & $\stackrel{n}{\simeq}$ & 1 & $\frac{\sim}{m}$ & 1 & 1 & $\begin{array}{l}\stackrel{n}{\infty} \\
\underline{\infty}\end{array}$ & $\stackrel{\infty}{\tilde{y}}$ & 1 & 1 & 1 \\
\hline & & & $E$ & $\dot{i}$ & ชี & 1 & $\tilde{\simeq}$ & 1 & $\begin{array}{l}\text { శ్ } \\
\text { }\end{array}$ & $\frac{\approx}{m}$ & $\frac{n}{m}$ & 1 & 1 & $?$ \\
\hline & & \multirow{2}{*}{$\begin{array}{l}\frac{y}{4} \\
\sigma \\
\sigma\end{array}$} & $z$ & $\tilde{\sigma}$ & 1 & 1 & $\begin{array}{l}\hat{\infty} \\
\stackrel{0}{0}\end{array}$ & 1 & 1 & ชี & 1 & $\simeq$ & 1 & ปี่ \\
\hline & & & $E$ & $\begin{array}{l}\underset{+}{*} \\
\stackrel{\infty}{\infty}\end{array}$ & ชే & 1 & 1 & 1 & 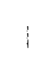 & స్ & I & 1 & 1 & సู \\
\hline & & $\begin{array}{l}0 \\
\stackrel{0}{0} \\
\sum_{0}^{2}\end{array}$ & & 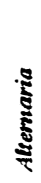 & 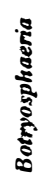 & 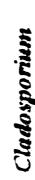 & 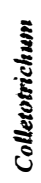 & 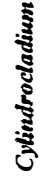 & 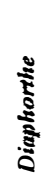 & 㺼 & है & $\begin{array}{l}0 \\
0 \\
0 \\
0\end{array}$ & ב气 & \\
\hline
\end{tabular}

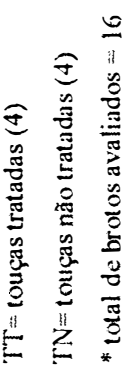


Representantes do gênero Phoma, apareceram somente no início do levantamento, correspondendo a isolamentos feitos a partir de material colhido no primeiro ciclo, ou seja nos meses de outubro/novembro de 96 .

Os gêneros Nigrospora e Penicillium também ocorreram esporadicamente, sendo que Nigrospora apareceu pela primeira vez em outubro/96 e somente voltou a aparecer em junho/97. Penicillium apareceu uma única vez no mês de dezembro/96, sendo isolado de um único broto.

O gênero Diaporthe também apresentou baixa freqüência de ocorrência, aparecendo apenas em três épocas de coleta, ou seja, nos meses de novembro/96, dezembro/96 e março/97, porém isolado de somente um broto em cada uma dessas épocas.

O gênero Cladosporium foi o único gênero que, apesar de se manifestar com baixa freqüência durante o levantamento, apareceu constantemente no período de junho/97 até outubro/97.

O gênero Cylindrocladium apresentou baixa freqüência, ocorrendo apenas no $2^{\circ}$ e no $3^{\circ}$ ciclos de corte, sendo que neste último caso, isolados foram obtidos tanto da amostra coletada aos 40 como aos 60 dias. Esses resultados concordam com as observações de Souza \& Krügner (1995), Fisher et al. (1993) e Smith \& Wingfield (1996) quanto à associação deste fungo patogênico com a podridão de estacas. Ressaltase que dentre todos os gêneros identificados ao longo do trabalho, o reconhecimento de espécie só foi possível para o gênero Cylindrocladium. Os procedimentos para isto envolveram o uso de microscopia eletrônica de varredura, onde foram determinadas algumas características morfológicas do fungo como tamanho e 
septação do conídio, tamanho de estipe, vesícula e fiálide. Estas caracteristicas permitiram identificar a espécie Cylindrocladium candelabrum Viegas, conforme Crous \& Wingfield (1994).

O gênero Fusarium foi constatado em isolamentos realizados com brotos provenientes do $1^{\circ}$ e $2^{\circ}$ ciclos de corte, sendo novamente detectado nos isolamentos subseqüentes, correspondentes ao $4^{\circ}$ e $5^{\circ}$ ciclos de corte.

O fungo Guignardia sp apresentou uma alta freqüência nos isolamentos, sendo encontrado no $1^{\circ}$ ciclo de corte (segunda amostragem), $2^{\circ}$ ciclo de corte (nas duas amostragens), $3^{\circ}$ ciclo de corte (nas duas amostragens), $4^{\circ}$ ciclo de corte (nas duas amostragens), $5^{\circ}$ ciclo de corte (primeira amostragem) e $6^{\circ}$ ciclo de corte (única amostragem). Em vários isolamentos a porcentagem de brotos portadores do fungo foi bastante alta, como por exemplo durante o $1^{\circ}$ ciclo de corte (segunda amostragem), onde, entre touças tratadas e não tratadas, o isolamento do fungo foi positivo em mais de $80 \%$ dos brotos amostrados. A partir de abril/97, o fungo teve sua freqüência diminuida e passou a ocorrer em baixa porcentagem de brotos, voltando a aparecer somente a partir de outubro/novembro/97.

O gênero Botryosphaeria também ocorreu com alta freqüência durante o levantamento, sendo constatado no $1^{\circ}, 2^{\circ}$ e $3^{\circ}$ ciclos de corte (duas amostragens) e no $4^{\circ}$ ciclo de corte (segunda amostragem). Na segunda amostragem do $3^{\circ}$ ciclo de corte, o fungo foi isolado de mais de $50 \%$ dos brotos coletados, considerando as touças tratadas e não tratadas. A partir de março/97 a freqüência de ocorrência diminuiu consideravelmente. 
O gênero Alternaria se manifestou com alta freqüência, tendo aparecido durante os três primeiros ciclos de corte (nas duas amostragens) e no $4^{\circ}$ e $5^{\circ}$ ciclos de corte (segunda amostragem). A porcentagem dos brotos infectados no início do ensaio $\left(1^{\circ}\right.$ e $2^{\circ}$ ciclo) foi maior em relação à presença do fungo nos brotos coletados no $3^{\circ}, 4^{\circ}$ e $5^{\circ}$ ciclos de corte.

O gênero Colletotrichum foi aquele que apresentou maior freqüência, sendo constatado em todos os ciclos de corte, com exceção apenas na segunda amostragem do $5^{\circ}$ ciclo. De acordo com os resultados, pode-se observar que, na maioria das amostragens, esse gênero esteve presente em uma porcentagem bastante alta dos brotos.

O levantamento da população fúngica endofitica associada a brotos de eucalipto evidenciou a presença de alguns gêneros previamente assinalados como endofiticos para outras espécies vegetais arbóreas, que não o eucalipto. Assim, Carrol (1990) relatou a ocorrência do gênero Fusarium em vários hospedeiros. Fischer et al. (1992) constataram a presença de mais de uma espécie de Colletotrichum e de Alternaria em plantas do gênero Thymus, enquanto Johnson et al. (1992) relataram o isolamento de G. cingulata, Dothiorella spp e de A. alternata em tecidos do caule de mangueira. Também Pusey \& Bertrand (1993) detectaram a ocorrência endofitica de B. dothidea em material de pessegueiro aparentemente sadio.

Para o caso específico do eucalipto, alguns gêneros de fungos isolados e identificados neste trabalho também foram constatados por outros autores como ocorrendo endofiticamente em plantas deste gênero. Fischer et al. (1993) obtiveram frequentemente $B$. dothidea em isolamentos sucessivos feitos a partir da casca, ramos e folhas. Vitti et al. (1989) isolaram fungos do gênero Cylindrocladium de $20 \%$ das 
estacas destinadas a produção de mudas, enquanto Souza \& Krugner (1995) relataram a ocorrência de B. ribis e Colletotrichum sp em brotos provenientes de jardim clonal.

\subsection{Teste de patogenicidade}

Os resultados do teste de patogenicidade (Tabela 2 e Tabela 3) mostraram que dentre os gêneros de fungos mais freqüentemente isolados de amostras do jardim clonal, Colletotrichum, Botryosphaeria e Cylindrocladium estão envolvidos no complexo da podridão de estacas.

A espécie C. candelabrum, esteve associada a $82,8 \%$ das estacas plantadas em substrato infestado experimentalmente por este patógeno. Os dados de severidade, medida através do comprimento da lesão, mostraram um comprimento médio de área escurecida, da ordem de $33 \mathrm{~mm}$. Os fungos pertencentes aos gêneros Botryosphaeria e Colletotrichum apresentaram uma incidência menor do que C. candelabrum, estando ambos associados a aproximadamente $32 \%$ das estacas plantadas em solo infestado experimentalmente por esses patógenos. Em relação à severidade, a média do comprimento de lesão de estacas do tratamento com o gênero Colletotrichum atingiu cerca de $12 \mathrm{~mm}$, enquanto para o tratamento com o gênero Botryosphaeria a média do comprimento das lesões foi em torno de $20 \mathrm{~mm}$. 
Os resultados de reisolamento (Tabela 2) mostraram que o gênero Colletotrichum foi recuperado de $48 \%$ das estacas que apresentavam sintomas de escurecimento, enquanto Botryosphaeria foi reisolado de $66 \%$ das estacas plantadas em substrato infestado com este fungo e C. candelabrum apareceu em $95 \%$ das estacas com sintomas de podridão, provenientes do substrato artificialmente infestado. A presença de $C$. candelabrum também foi registrada em $9,5 \%$ das estacas infectadas pelo gênero Colletotrichum e em $28 \%$ das estacas infectadas por Botryosphaeria.

Apesar de $C$. candelabrum ter aparecido em reisolamentos dos gêneros Colletotrichum e Botryosphaeria, ficou evidente que estes dois gêneros estão consistentemente associados à podridão de estacas. Por outro lado, a alta patogenicidade de $C$. candelabrum ficou demonstrada pela sua alta incidência nas estacas plantadas em substrato infestado por ele próprio e pelo seu aparecimento em reisolamentos feitos em estacas plantadas em substratos infestados pelos gêneros Colletotrichum, Botryosphaeria, Alternaria e Guignardia.

O escurecimento da parte basal das estacas plantadas em substrato infestado com Alternaria e Guignardia e das estacas plantadas em substrato não infestado (tratamento testemunha), podem ser creditado ao gênero Colletotrichum e a espécie C. candelabrum, como pode ser visto nos resultados de reisolamento apresentados na Tabela 2. A incidência de podridão e o sintoma de escurecimento presente nas estacas plantadas em substratos sem infestação e em substrato infestado por Alternaria e Guignardia pode ser atribuído à presença de Colletotrichum e $C$. candelabrum, pois estes fungos foram detectados na fase de reisolamento, não sendo constatada a ocorrência nem de Alternaria nem de Guignardia neste material. Estes resultados não só demonstraram o 
envolvimento destes fungos em relação à podridão como confirmam a ocorrência endofitica dos mesmos, os quais possivelmente vieram junto com as estacas obtidas a partir de brotos retirados de plantas do jardim clonal.

Os resultados obtidos na avaliação feita aos 12 dias foram confirmados pela avaliação feita aos 25 dias após a estaquia. Nesta última avaliação, os resultados obtidos para incidência e comprimento de área apodrecida foram maiores que aqueles obtidos aos 12 dias, porém a análise dos resultados leva a às mesmas conclusões, inclusive para o caso de reisolamentos (Tabela 3 ).

A associação de C. candelabrum e fungos dos gêneros Colletotrichum e Botryosphaeria à podridão de estacas também tem sido relatada por outros autores que se dedicaram ao estudo da etiologia da doença. Vitti et al. (1989) relataram a presença do primeiro gênero em $20 \%$ de estacas com podridão, enquanto o segundo e terceiro gêneros foram assinalados em $15 \%$ e $11 \%$ das estacas. Estes autores se referem ao Cylindrocladium como um gênero patogênico e fazem a suposição de que Colletotrichum e Botryosphaeria possivelmente possam atuar como patógenos secundários. Carvalho et al. (1989) isolaram, com maior frequência, fungos do gênero Cylindrocladium como patógenos de estacas em fase de enraizamento e consideraram Botryosphaeria sp como patógeno secundário. Também Souza \& Krugner (1995) detectaram a presença de $B$. ribis e de Colletotrichum sp em brotos de jardim clonal e destacaram que estes gêneros poderiam atuar como potenciais patógenos em relação ao desenvolvimento de podridão em estacas. Apesar de constantemente apontados em vários artigos como patógenos secundários ou como potenciais patógenos, no presente trabalho foi evidenciada a associação de Colletotrichum e Botryosphaeria com a 
podridão ocorrendo em uma elevada porcentagem de estacas sintomáticas e experimentalmente inoculadas, provocando escurecimento de áreas consideráveis em relação ao tamanho das estacas.

Tabela 2. Patogenicidade e reisolamento dos fungos endofiticos mais frequentemente associados às brotações assintomáticas de jardim clonal e seu efeito sobre a formação de calos de estacas de eucalipto, avaliados aos 12 dias após a estaquia.

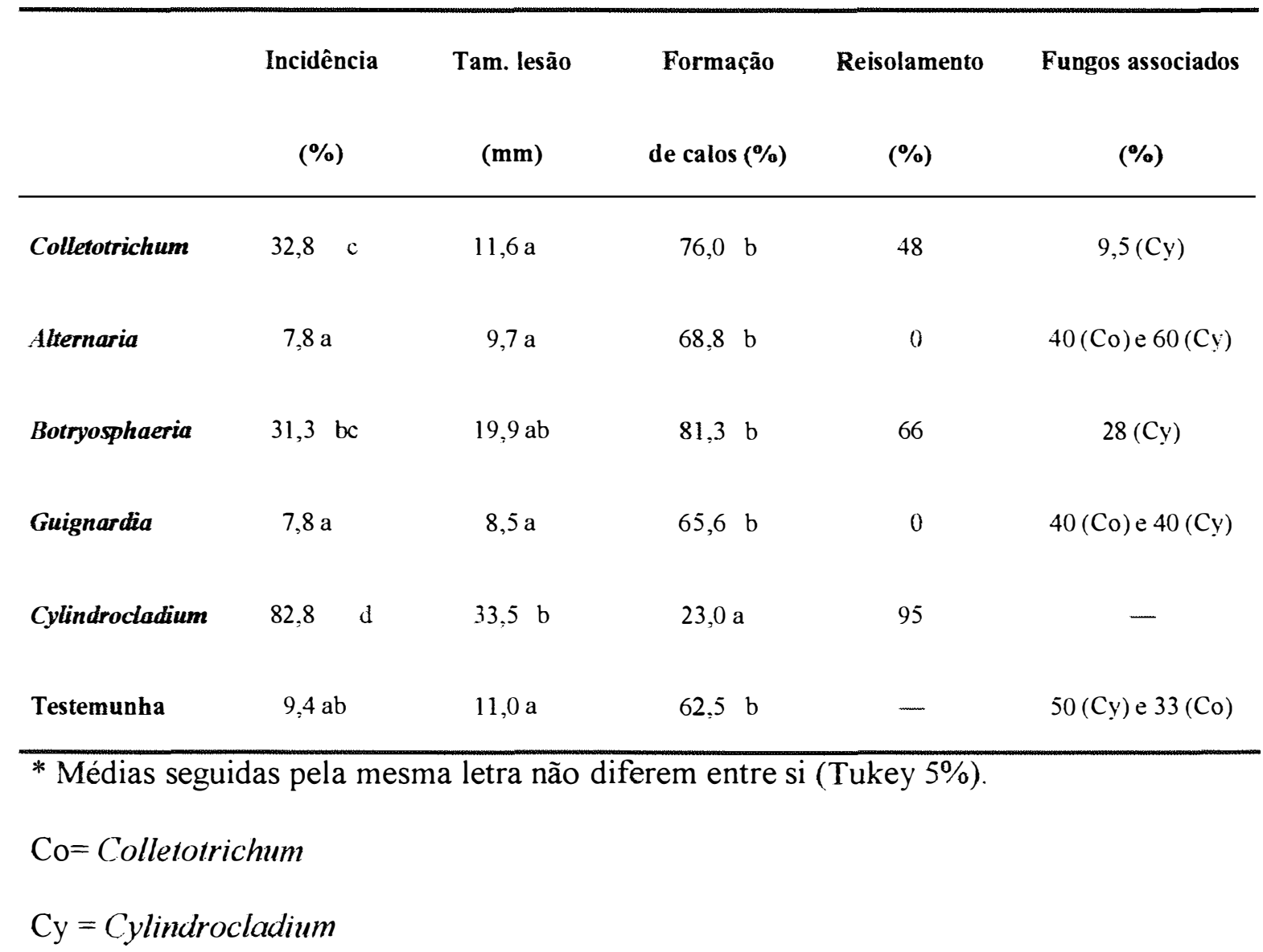


Tabela 3. Patogenicidade e reisolamento dos fungos endofiticos mais frequentemente associados às brotações assintomáticas de jardim clonal e seu efeito sobre o enraizamento de estacas de eucalipto, avaliados aos 25 dias após a estaquia.

\begin{tabular}{|c|c|c|c|c|c|}
\hline & Incidência & Tam. lesão & Enraizamento & Reisolamento & Fungos associados \\
\hline & $(\%)$ & $(\mathbf{m m})$ & $(\%)$ & $(\%)$ & $(\%)$ \\
\hline Colletotrichum & $37,5 \mathrm{bc}$ & $32,7 \mathrm{ab}$ & $23,4 \mathrm{a}$ & 36 & $24(C y)$ \\
\hline Alternaria & $20,6 \mathrm{ab}$ & $21,9 \mathrm{a}$ & $17,2 \mathrm{a}$ & - & $84,6(C y)$ \\
\hline Botryosphaeria & $51,9 \quad \mathrm{c}$ & $31,8 \mathrm{ab}$ & $25,0 \mathrm{a}$ & 30 & $30(C y)$ \\
\hline Guignardia & $12,5 \mathrm{a}$ & $20,6 a$ & $20,0 \mathrm{a}$ & 0 & $66(C y)$ \\
\hline Cylindrocladium & $96,8 \quad d$ & $51,2 \mathrm{~b}$ & $1,5 \mathrm{a}$ & 100 & - \\
\hline Testemunha & $9,4 \mathrm{a}$ & $20,4 \mathrm{a}$ & $23,4 \mathrm{a}$ & - & $24(\mathrm{~B}) ; 20(\mathrm{Co}) ; 40(\mathrm{Cy})$ \\
\hline \multicolumn{6}{|c|}{ * Médias seguidas pela mesma letra não diferem entre si (Tukey $5 \%$ ). } \\
\hline \multicolumn{6}{|c|}{$\mathrm{B}=$ Botryosphaeria } \\
\hline \multicolumn{6}{|c|}{$\mathrm{Co}=$ Colletotrichum } \\
\hline $\mathrm{Cy}=C y$ lindrc & lium & & & & \\
\hline
\end{tabular}


O envolvimento de Colletotrichum e Botryosphaeria no complexo da podridão, pode ser explicado com base no artigo de Smith et al. (1996), os quais mencionam que a espécie Phialocephala sp que ocorria endofiticamente em eucalipto passou a induzir sintomas em plantas que sofreram estresse. Com base nessa observação, pode-se inferir que o estresse provocado durante a formação da muda, a partir dos brotos coletados em jardim clonal, poderia predispor a muda ao ataque tanto de Colletotrichum como de Botryosphaeria.

O gênero Alternaria foi isolado como um fungo endofitico, porém não foi evidenciada a sua patogenicidade, concordando com relatos feitos em outros trabalhos (Fischer et al. 1992; Johnson et al. 1992). O aparecimento de Guignardia nos brotos de jardim clonal é um fato novo, uma vez que não foram encontradas referências em outros trabalhos sobre a sua ocorrência como fungo endofitico. No entanto, o fungo se mostrou não patogênico em relação à podridão.

A ação dos diferentes gêneros de fungos mais frequentemente isolados de brotos do jardim clonal sobre a formação de calos e enraizamento de estacas pode ser interpretada com base nos resultados apresentados na Tabela 2 e Tabela 3.

Os gêneros Alternaria e Guignardia, embora aparentemente causem redução na formação de calos e enraizamento de estacas, não aparecem no reisolamento; no entanto, a presença marcante de $C$. candelabrum associada às estacas inoculadas com esses dois gêneros indica que esta espécie é a responsável pela doença e que a mesma está atuando na redução de calos e enraizamento. Por outro lado, os resultados mostram que os gêneros Colletotrichum e Botryosphaeria estão associados à podridão e que ambos podem estar interferindo na produção de calos e raizes pelas estacas, apesar de $C$. 
candelabrum ter aparecido também associada a estes fungos durante o reisolamento. $\mathrm{O}$ fato de se observar lesões relativamente desenvolvidas nas estacas atacadas por Colletotrichum e Botryosphaeria, a formação de calos não foi afetada, pois as lesões estavam ocorrendo em grande parte das estacas superiormente em relação à região de formação de calos.

O papel de $C$. candelabrum sobre a formação de calos e enraizamento foi evidente, embora sem significância estatística, pois estacas plantadas em substrato infestado pelo fungo apresentaram redução de $70 \%$ e quase $100 \%$, respectivamente, para estas características. Com base nos resultados obtidos neste trabalho e como já assinalado em outros artigos (Demuner et al., 1988 b; Carvalho et al.,1989 e Vitti et al., 1989), fungos do gênero Cylindrocladium são os grandes responsáveis pela redução na produção de mudas de eucalipto pelo método de estaquia, por causarem podridão e, consequentemente, afetarem o enraizamento das estacas.

\subsection{Tratamento de touças no jardim clonal}

De acordo com os resultados da Tabela 1, pode-se perceber que o tratamento das touças com os fungicidas benomyl intercalado com oxicloreto de cobre não foi eficiente para o controle de microrganismos endofiticos. Em alguns casos, touças tratadas chegaram a apresentar freqüência maior de microrganismos do que touças não tratadas. 
No entanto, alguns fungos, como por exemplo os gêneros Botryosphaeria, Guignardia e Colletotrichum, foram isolados com maior freqüência de touças localizadas em jardim clonal não tratado. O tratamento químico das touças somente mostrou algum efeito em relação a C. candelabrum, pois nos três isolamentos em que o fungo foi detectado, os brotos eram oriundos de touças não tratadas com os fungicidas.

A baixa eficiência do tratamento químico das touças talvez possa ser aribuído, entre outras causas, à época e forma de aplicação dos fungicidas. Em relação à época, quando os brotos são retirados das touças, os ferimentos, provocados pelo corte, servem como portas de entrada para patógenos. A aplicação de fungicidas somente é feita duas semanas após o corte, época em que estas touças apresentam novas brotações, justamente para a proteção desses novos brotos que fornecerão as estacas para produção de mudas. A penetração de fungos pode, portanto, ocorrer através dos ferimentos, cuja superficie se encontra desprotegida pelos fungicidas. Assim, quando as pulverizações são feitas os fungos já se encontram endofiticamente. Quanto à forma de aplicação, embora o benomyl tenha ação sistêmica, o seu efeito sobre o patógeno endofitico pode não ser exercido adequadamente em função da quantidade absorvida pela planta não ser suficiente, pois quando o produto é aplicado via folha o mesmo é muito pouco absorvido, como foi demonstrado por Bedendo \& Krügner (1988). Estes mesmos autores relataram que aplicações feitas no solo controlaram mais eficientemente Cylindrocladium sp em eucalipto, pois o fungicida foi absorvido em maior quantidade e de maneira contínua (Bedendo \& Krugner, 1987). 
Diante dessas evidências, pode-se sugerir a aplicação de fungicidas imediatamente após o corte dos brotos, com o objetivo de previnir a penetração de fungos através de ferimentos. Ainda, a aplicação de sistêmicos poderia ser feita na forma de rega, possibilitando às plantas maior absorção do produto. Quanto ao custo da aplicação no solo, este seria justificável, pois áreas de jardim clonal são relativamente pequenas quando comparadas com as áreas de campo comercial.

\subsection{Tratamento químico de estacas}

O tratamento químico de estacas feito com benomyl e captan não se mostrou eficiente. A incidência de podridão não foi reduzida em relação à testemunha, o mesmo ocorrendo com o tamanho das lesões e formação de calos/enraizamento, tanto para a avaliação realizada aos 12 como aos 25 dias (Tabelas 4 e 5). Comparando-se os resultados obtidos nas duas avaliações, pode ser notado que os valores para incidência e tamanho de lesão são maiores na segunda a valiação, porém somente reforçam os dados obtidos na primeira avaliação. A análise dos resultados mostra que não houve diferença significativa quando se comparou incidência e tamanho de lesão entre as estacas tratadas e não tratadas. Resultados semelhantes foram obtidos para as características formação de calos, medida aos 12 dias, e enraizamento, a valiado aos 25 dias. 
Uma possível explicação para a ineficiência do tratamento fungicida possa ser baseada no fato dos fungos ocorrerem endofiticamente. A atuação do fungicida pode ficar restrita à superficie da estaca, não atingindo os tecidos mais internos onde se encontram os fungos. Embora o tratamento fungicida não reduza a incidência de podridão e o tamanho das lesões, o mesmo parece exercer um certo controle sobre $C$. candelabrum, pois este fungo não aparece nos tratamentos onde se utilizou benomyl. Como C. candelabrum tem sido apontado como o principal agente associado ao complexo da podridão e como o custo do tratamento fungicida não é relevante para a produção de mudas, sugere-se o emprego do mesmo como uma das etapas da produção comercial de mudas de eucalipto. 
Tabela 4. Efeito de tratamento fungicida sobre a ocorrència de podridão e formação de calos em estacas de eucalipto, avaliado 12 dias após a estaquia.

\begin{tabular}{lcccc}
\hline & $\begin{array}{c}\text { Incidência } \\
(\mathbf{\%})\end{array}$ & $\begin{array}{c}\text { Tamanho lesão } \\
(\mathbf{m m})\end{array}$ & $\begin{array}{c}\text { Formação } \\
\text { de calos }(\%)\end{array}$ & $\begin{array}{c}\text { Isolamento } \\
\text { de fungos (\%) }\end{array}$ \\
\hline Benlate & $12,3 \mathrm{a}$ & $12,1 \mathrm{a}$ & $65,7 \mathrm{a}$ & $7,6(\mathrm{~B})$ \\
Captan & $11,4 \mathrm{a}$ & $15,2 \mathrm{a}$ & $77,1 \mathrm{a}$ & $17(\mathrm{Co})$ \\
Testemunha & $25,7 \mathrm{a}$ & $12.2 \mathrm{a}$ & $65,7 \mathrm{a}$ & $18(\mathrm{Co}) ; 30(\mathrm{~B})$ \\
\hline * Médias seguidas pela mesma letra não diferem entre si (Tukey 5\%) & & \\
B= Botryosphaeria & & & & \\
Co= Colletotrichum & & &
\end{tabular}

Tabela 5. Efeito de tratamento fungicida sobre a ocorrência de podridão e enraizamento em estacas de eucalipto, avaliado 25 dias após a estaquia.

\begin{tabular}{|c|c|c|c|c|}
\hline & $\begin{array}{c}\text { Incidência } \\
(\%)\end{array}$ & $\begin{array}{c}\text { Tamanho lesão } \\
(\mathrm{mm})\end{array}$ & $\begin{array}{c}\text { Enraizamento } \\
(\%)\end{array}$ & $\begin{array}{c}\text { Isolamento } \\
\text { de fungos }(\%)\end{array}$ \\
\hline Benlate & $16,2 \mathrm{a}$ & $23,4 \mathrm{a}$ & $25,6 \mathrm{a}$ & $13 \mathrm{~B} ; 53(\mathrm{Co})$ \\
\hline Captan & $14,3 \mathrm{a}$ & $30,2 \mathrm{a}$ & $29,5 \mathrm{a}$ & $13(\mathrm{Cy}) ; 40(\mathrm{Co})$ \\
\hline Testemunha & $15,1 \mathrm{a}$ & $26,0 \mathrm{a}$ & $31,4 \mathrm{a}$ & $13(\mathrm{Cy}) ; 40(\mathrm{Co})$ \\
\hline \multicolumn{5}{|c|}{ * Médias seguidas pela mesma letra não diferem entre si (Tukey $5 \%$ ) } \\
\hline \multicolumn{5}{|c|}{$\mathrm{B}=$ Botryosphaeria } \\
\hline \multicolumn{5}{|c|}{$\mathrm{Co}=$ Colletotrichum } \\
\hline $\mathrm{Cy}=C y$ lina & & & & \\
\hline
\end{tabular}




\section{CONCLUSÕES}

Com base nos resultados obtidos no levantamento da população fúngica associada a brotos do jardim clonal, nos testes de patogenicidade realizados com os fungos mais frequentemente isolados dos brotos e no tratamento químico de matrizes e de estacas utilizadas para a produção de mudas, pode-se concluir que:

a) Os gêneros Colletotrichum, Botryosphaeria e Guignardia foram aqueles que ocorreram com maior frequência em brotos assintomáticos.

b) A espécie Cylindrocladium candelabrum se mostrou altamente patogênica, causando podridão e redução de enraizamento em estacas de eucalipto.

c) Os gêneros Colletotrichum e Botryosphaeria estão também associados ao complexo da podridão de estacas, sem no entanto causar redução significativa no enraizamento das estacas. 
d) $\mathrm{O}$ tratamento semanal de touças com os fungicidas benomyl $(0,5 \mathrm{~kg} / \mathrm{ha})$ e oxicloreto de cobre $(1,1 \mathrm{~kg} / \mathrm{ha})$, a plicados duas semanas após o corte de brotos em pulverização foliar, não foi eficiente para controlar os fungos que ocorreram endofiticamente.

e) O tratamento de estacas obtidas de brotos do jardim clonal com os fungicidas benomyl $(0,75 \mathrm{~g} / \mathrm{l})$ e captan $(1,5 \mathrm{~g} / \mathrm{l})$ por imersão durante 5 minutos não apresentou efeito positivo sobre o controle da podridão de estacas. 


\section{REFERÊNCIAS BIBLIOGRÁFICAS}

ALFENAS, A.C.; DEMUNER, N.L.; SILVA, A.R. Resistência de Cylindrocladium scoparium, agente etiológico de podridão em estacas de Eucalyptus a benomyl. Fitopatologia Brasileira, v. 12, n. 2, p. 158, 1989 (Resumo).

ALFENAS, A.C.; DEMUNER, N.L.; SILVA, A.R. Benomyl resistant strain of Cylindrocladium scoparium, causal agent of cutting rot of Eucalyptus grandis in Brazil. ISPP - Chemical Control Newsletter, n. 10, p. 23-25, 1988.

ANDRADE, E.V. O Eucalipto. São Paulo, 1961, 667 p..

BEDENDO, I.P.; KRÜGNER, T.L. Persistence of Benomyl in seedlings of Eucalyptus cloeziana and Eucalyptus grandis after soil application. Fitopatologia Brasileira, v. 13, n. 3 , p. $227-230,1988$ 
BEDENDO, I.P.; KRÜGNER, T.L. Fungitoxicidade de benomyl e chlorothalonil a Cylindrocladium pteridis e sua persistência após pulverização em folhas de Eucalyptus cloezina. Fitopatologia Brasileira, v. 12, n. 3, p. 236-239, 1987.

CARDOSO, J.E.; COSTA, J.L.S. Efeito do tratamento de semente de feijão e caupi no controle da podridão radicular de Rhizoctonia e da podridão do colo de Sclerotium. Fitopatologia Brasileira, v. 13, n. 2, p. 136, 1988.

CARROL, G.C. Fungal endophytes in vascular plants: mycological research opportunities in Japan. Transactions of the Mycological Society of Japan, v. 31, n. 1, p. 103-116, 1990.

CARVALHO, A.O.; ALFENAS, A.C.; DEMUNER, N.L. Patogenicidade de fungos isolados de estacas de eucalipto para enraizamento em casa de vegetação. Fitopatologia Brasileira, v. 14, n. 2, p. 122, 1989 (Resumo).

CROUS, P.W.; WINGFIELD, M.J. A monograph of Cylindrocladium including anamorphus of calonectria. Mycotaxon, Ithaca, v. 51, p. 341-345, 1994.

DEMUNER, N.L.; FERREIRA, F.A.; ALFENAS, A.C.; DEMUNER, A.J. Erradicação "in vitro" de conídios e micélio de Cylindrocladium scoparium com benomyl, captan, thiram e hipoclorito de sódio. Fitopatologia Brasileira, v. 13, n. 2, p. 127, 1988 a (Resumo). 
DEMUNER, N.L.; FERREIRA, F.A.; ALFENAS, A.C., REZENDE, D.V. Análise técnica da prática de imersão de base de estacas em suspensão de benomyl para prevenção do apodrecimento de estacas de eucalipto para enraizamento. Fitopatologia Brasileira, v. 13, n. 2, p. 307-313, 1988 b (Resumo).

FERREIRA, F.A. Principais doenças florestais no Brasil. Patologia Florestal. Viçosa. Sociedade de Investigações Florestais. 1989, 570 p..

FERREIRA, F.A.; DEMUNER, N.L.; ALFENAS, A.C.; DEMUNER, A.J. Análise do tratamento de estacas de eucalipto para enraizamento com benomyl e bioensaios para erradicação de esporos e outras estruturas fúngicas em BDA. Fitopatologia Brasileira, v. 17, n. 3, p. 307-313, 1992.

FISHER, P.J.; PETRINI, O. Location of fungal endophytes in tissues of Suaeda fruticosa: a preliminary study. Transactions of the British Mycological Society. v. 89 , n. 2 , p. $246-249,1987$.

FISHER, P.J.; PETRINI, O.; AMEZQUITA, M.M. Endophytic fungi from Alpine and Mediterranean species of Thynus. Nova Hedwigia, v. 55, n. 3-4, p. 473-477, 1992.

FISHER, P.J.; PETRINI, O.; SUTTON, B.C. A comparative study of fungal endophytes in leaves, xylem and back of Eucalyptus in Australia and England. Sydowia, v. 45, n. 2, p. 338-345, 1993 
FRASER, D.; DAVISON, E.M. Stern cankers of Eucalyptus saligna in western Australia. Australian - Forestry, v. 48, n. 4, p. 220-226, 1985.

GINDRAT, D.; PEZET, R. Paraquat, a tool for rapid detection of latent fungal infections and of endophytic fung. Journal of Phytopathology, v. 141, n. 1, p. 86-98, 1994.

HATA, K.; FUTAI, K. Variation in fungal endophyte populations in needles of the genus Pinus. Canadian Journal of Botany, v. 74, n. 1, p. 103-114, 1996.

JOHNSON, G.I.; MEAD, A.J.; COOKE, A.W.; DEAN, J.R. Mango stem end rot pathogens - fruit infection by endophytic colonization of the inflorescence and pedicel. Annals of Applied Biology, v. 120, n. 2, p. 225-234, 1992.

ONU- Organização das Nações Unidas para a Alimentação e a Agricultura. Roma, 1989.

PUNITHALINGAN, E.; HOLLIDAY, P. Botryosphaeria ribis. CMI Descriptions of Pathogenic Fungi and Bacteria. N. 395, 1973.

PUSEY, P.L. \& BERTRAND, P.L. Seasonal infection of nonwounded Peach Bark by Botryosphaeria dothidea. Phytopathology. v. 83, n. 8, p. 825-829, 1993.

SMITH, O.C. Inoculations showing the wide host range of Botryosphaeria ribis. Journal of Agricultural Research, v. 49, n. 5, p. 467-476, 1934. 
SMITH, H.; KEMP, G.H.J.; WINGFIELD, M.J.; Canker and "die back" of Eucalyptus in South Africa caused by Botryosphaeria dothidea. Plant Pathology, v. 43, n. 6, p. $1031-1034,1994$.

SMITH, H.; WINGFIELD, M.J.; CROUS, P.W.; COUTINHO, T.A. Sphaeropsis sapinea and Botryosphaeria dothidea endophytica in Pinus spp. and Eucalyptus spp. in South Africa. South African Journal of Botany, v. 62, n. 2, p. 86-88, 1996.

SOUZA, M.F.; KRÜGNER, T.L. Ocorrência de Botryosphaeria ribis e Colletotrichum sp. associados a brotações em jardim clonal e a podridão de estacas de Eucalyptus. III simpósio de Iniciação Científica da Universidade de São Paulo, p. 400, Novembro 1995.

TAKAHASHI, S.S.; FURTADO, E.L.; CAMARGO, F.R.A.; RAMIRO, G.A. Controle das principais doenças que ocorrem em estacas de Eucalyptus spp. na fase de enraizamento. In: XXI Congresso Paulista de Fitopatologia, Faculdade de Ciências Agronômicas, Botucatu, 1998. Anais. Botucatu, 1998. p. 121.

TAKAHASHI, S.S.; FURTADO, E.L. Avaliação da sensibilidade "in vitro" dos principais patógenos que ocorrem em viveiros de Eucalyptus spp. a diferentes doses e formulações de Fegatex. In: XXI Congresso Paulista de Fitopatologia, Faculdade de Ciências Agronômicas, Botucatu, 1998. Anais. Botucatu, 1998. p. 122. 
VITTI, A.N.; KRÜGNER, T.L.; VIEIRA, J.D. Etiologia da podridão de estacas de Eucalyptus spp. em casa de vegetação. Fitopatologia Brasileira, v. 14, n. 2, p. 116 , 1989 (Resumo). 